\title{
Use of Nanotechnology for the Bioremediation of Contaminants: A Review
}

\author{
Edgar Vázquez-Núñez ${ }^{1, * \mathbb{C}}$, Carlos Eduardo Molina-Guerrero ${ }^{1}$, Julián Mario Peña-Castro ${ }^{2}$, \\ Fabián Fernández-Luqueño ${ }^{3}$ (1) and Ma. Guadalupe de la Rosa-Álvarez ${ }^{1}$ \\ 1 Departamento de Ingenierías Química, Electrónica y Biomédica, División de Ciencias e Ingenierías, \\ Campus León, Universidad de Guanajuato, Lomas del Bosque 103, Lomas del Campestre, \\ León, Guanajuato C.P. 37150, Mexico; cmolina@fisica.ugto.mx (C.E.M.-G.); \\ delarosa@ugto.mx (M.G.d.1.R.-Á.) \\ 2 Laboratorio de Biotecnología Vegetal, Instituto de Biotecnología, Universidad del Papaloapan, Tuxtepec, \\ Oaxaca C.P. 68333, Mexico; julianpc@unpa.edu.mx \\ 3 Programas en Sustentabilidad de los Recursos Naturales y Energía, Cinvestav Saltillo Industrial, \\ Parque Industrial, Ramos Arizpe, Coahuila C.P. 25900, Mexico; fabian.fernandez@cinvestav.edu.mx \\ * Correspondence: edgarvqznz@fisica.ugto.mx
}

Received: 22 May 2020; Accepted: 8 July 2020; Published: 13 July 2020

\begin{abstract}
Contaminants, organic or inorganic, represent a threat for the environment and human health and in recent years their presence and persistence has increased rapidly. For this reason, several technologies including bioremediation in combination with nanotechnology have been explored to identify more systemic approaches for their removal from environmental matrices. Understanding the interaction between the contaminant, the microorganism, and the nanomaterials (NMs) is of crucial importance since positive and negative effects may be produced. For example, some nanomaterials are stimulants for microorganisms, while others are toxic. Thus, proper selection is of paramount importance. The main objective of this review was to analyze the principles of bioremediation assisted by nanomaterials, nanoparticles (NPs) included, and their interaction with environmental matrices. It also analyzed the response of living organisms employed to remediate the contaminants in the presence of nanomaterials. Besides, we discuss the international regulatory frame applicable to these technologies and how they might contribute to sustainability.
\end{abstract}

Keywords: contaminants; nanomaterial; bioremediation; sustainability

\section{Introduction}

The industrial revolution has promoted economic prosperity, along with releasing a variety of pollutants into the environment [1]. During recent years, new technologies have been developed to increase the efficiency of the removal of pollutants, among them, bioremediation techniques have been proven to be a new and effective method for cleaning up pollutants in a variety of environments and a quite flexible management option to be implemented, also at a large scale [2].

Stimulation of the growth of indigenous microorganisms (biostimulation) or inoculation of non-native oil-degrading bacteria (bioaugmentation) were recognized as effective measures for accelerating the detoxification of a polluted site with a minimal impact on the ecological system [3]. Although bioremediation provides an excellent and flexible recovery strategy for different pollutants, it is poorly effective when dealing with high concentrations of the pollutants and xenobiotics or refractory compounds, causing unsustainable treatment efficiencies and recovery time [4].

In this context, the development of nanotechnology and the integration of the use of nanomaterials — defined as the particles with sizes of $100 \mathrm{~nm}$ or less in at least one dimension-and particularly 
nanoparticles - particles with two or three dimensions greater than $1 \mathrm{~nm}$-represents an innovative strategy to move the bioremediation forward beyond its limitations. This combined approach can include a wider range of potential applications with reduced costs and minimum negative impacts on the environment [5] for treating pollutants in groundwater and wastewater [6], sediments polluted with heavy metals and hydrocarbons [7], and either organic or inorganic compounds in soil [8].

Besides their positive effect on the removal of these contaminants, NMs could interact with biotic and abiotic elements, both in positive and negative ways; this is why many efforts have been conducted in order to evaluate the synergistic effect of the combined use of NMs and bioremediation practices and elucidate their physical, chemical and biological interactions either in soil or water [9].

So far, there are no consistent conclusions about whether the combined technologies are beneficial to improve pollutant removal efficiency and the combination of bioremediation technologies and nanomaterials to remove pollutants has not been widely reported, hence the main objective of this review is to examine bioremediation processes where nanomaterials are applied in order to enhance the removal of contaminants and describe their interactions with biotic and abiotic components during remediation processes and finally, some considerations regarding the international regulatory frame and world markets are mentioned.

\section{Principles of Nanobioremediation Technologies}

Every year around 10 million tons of toxic chemical compounds are released by industry [10-13]. After release, these compounds may further react to form chemicals, for instance, polychlorinated dibenzo-p-dioxins or polychlorinated dibenzofurans, which are by-products of certain chemical processes involving chlorine.

There is high variability in the physical and chemical properties of these chemical compounds, and their cytotoxicity and multiple interactions with biotic and abiotic environmental factors, i.e., microorganisms, plants, animals, water, minerals, organic matter, wind, etc., have complicated the successful implementation of remediation technologies [14-16]. The combined use of NMs and NPs with biotechnologies could offer a step-change in remediation capabilities, avoiding process intermediates, and increasing the speed of degradation $[17,18]$.

Besides physical and chemical technologies to remediate polluted sites, biological treatments have become relevant due to their low cost and wide range of applications [19]. Bioremediation includes biosorption, bioaccumulation, biotransformation, and biological stabilization, among others [20,21]. These technologies use plants and some microorganisms including bacteria and fungus, as well as combinations of them.

During recent years, NMs have been integrated with biological processes to accelerate and promote the removal of toxic compounds from the environment [22]. Cecchin et al. [23] use the term nanobioremediation for processes where NPs and microorganisms or plants are used to remove contaminants. Moreover, El-Ramady et al. [24] named these types of practices according to the nature of the organism utilized for the remediation of contaminants. Thus, they were more specific and named the techniques as phyto-nanoremediation, microbial nanoremediation, and zoo-nanoremediation.

In any case, since bioremediation uses living organisms to remediate contaminated environments, a proper interaction between nanoparticles (NPs) and living organisms is essential. In this context, some aspects are of paramount importance. For example, it is known that nanotoxicity, NPs size, and nanonutrition may affect the living organisms and this in turn may affect the whole bioremediation process.

Tan et al. [25] reported that the physical and chemical interactions between NMs, biota and contaminants depend on a variety of parameters including NMs size and shape, surface coating, chemical nature of the NMs and contaminant, type of organism, media, $\mathrm{pH}$, and temperature, among others; these interactions are represented in Figure 1. Given the number of potential parameters influencing such interactions, these phenomena become complex. For example, pH media as well as temperature play an essential role in the proper development of living organisms. These parameters in turn, may influence 
the stability of the NMs as well as that of the contaminant. For example, Wang et al. [26] proved that Au NPs were stable in MilliO water and a buffer; however, this stability was lost at pHs of 4, 7, 8 and 10. In addition, Tan et al. [27] proved that different synthetic methods influenced the thermal stability of Cu NPs. To the best of our knowledge, no comprehensive studies exist in the literature regarding the influence of the parameters shown above on the nanobioremediation of contaminants. Proper experimental designs should be applied to determine, for example, to what extent temperature and $\mathrm{pH}$ affect the synergistic effect of NMs and living organisms for the remediation of contaminants.

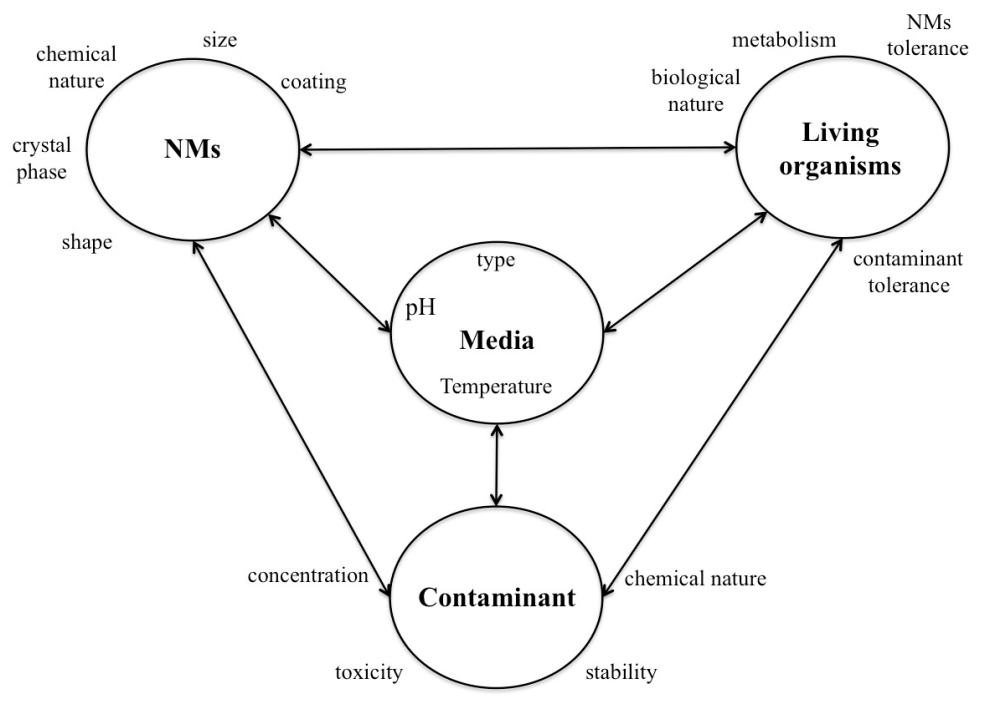

Figure 1. Different parameters influence the interaction of nanomaterials (NMs) and living organisms with the contaminants. Two-way arrows represent interactions.

Figure 2 displays some of the expected effects of the physicochemical interactions of NMs, contaminants, and biota. Once NPs and biota interact, different events may occur including dissolution, absorption, and biotransformation [28]. All events previously mentioned may participate in the degradation of the contaminants. In this case, metabolism is also involved. NPs may be either toxic or stimulant to living organisms and this results in a biocidal effect or a biostimulant effect, which may affect the performance of the organisms involved in the remediation process. Thus, the advantage of using both, NPs and living organisms, is the potential synergistic effect.

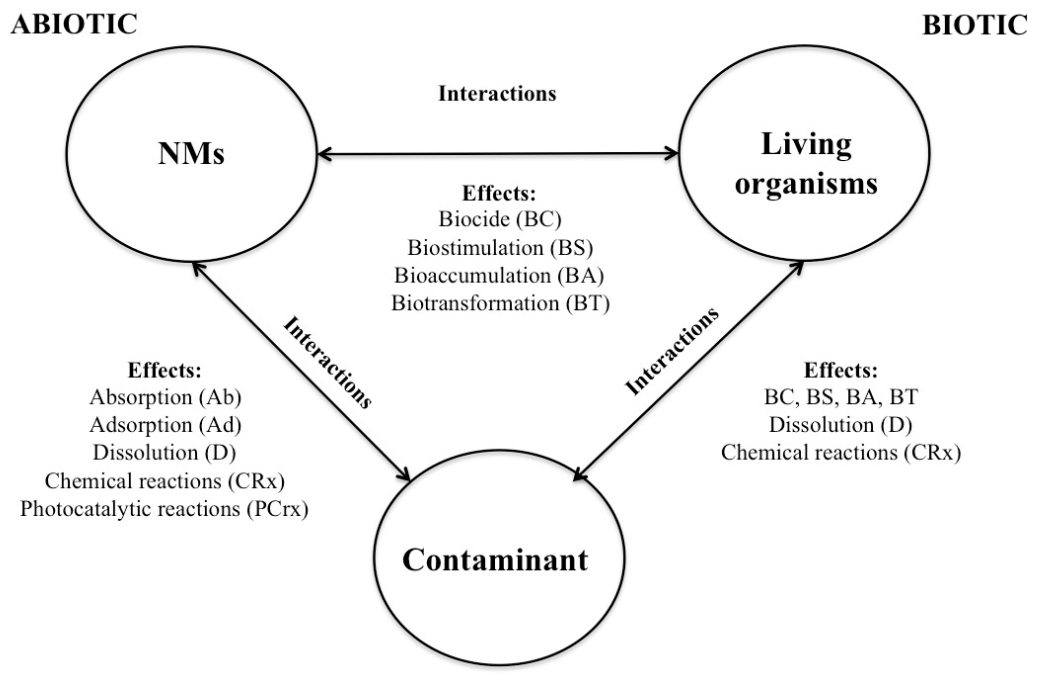

Figure 2. Different phenomena occur as a result of the physical, chemical, and biochemical interactions of NMs, living organisms, and contaminants during nanobioremediation processes. 
In nanobioremediation, sorption processes are essential. Sorption involves adsorption and absorption. In the first one, the interaction between the pollutant and the sorbent occurs at a surface level. Conversely, in the second one, the pollutant penetrates deeper layers of the sorbent to form a solution [29]. Moreover, a further distinction can be made. Chemisorption and physisorption are distinguished because, in the first one, a chemical reaction occurs, while in the second case only physical forces are involved. Whatever the case, in sorption, the contaminants may be immobilized, sequestered, and concentrated [29].

A significant amount of research has been performed to understand the nature of the adsorption processes using NMs [30-32]. Thus, mechanistic, thermodynamic, and kinetic studies are essential for describing the behavior of the nanomaterial when this material enters into contact with the contaminants. Some authors explicate several models that describe the behavior of including the biological matrix in remediation processes, i.e., the Freundlich and Temkin Isotherms, and the Langmuir and Dubinin-Radushkevich models [33-36].

Depending on the nature of the NMs, contaminants may be degraded by photocatalytic processes. The resultant products may be further biotransformed by the biotic systems and reduce the pollutant concentration in the media. In addition, some enzymes produced by living organisms may degrade a variety of contaminants [37].

Due to their size, NPs may even enter contaminated zones where other entities are not able to do so. Therefore, nanobioremediation technologies may extend their application fields [38]. This aspect represents an advantage over other remediation techniques. However, other considerations are necessary, for example, the standardization of protocols to evaluate the toxicity of nanoparticles and nanomaterials in soil and water, elucidation of their interactions with biotic and abiotic elements, and the applicable regulatory frame where these materials could be applied [39]. In conclusion, the selection of the NPs and the living organism represents a challenge and is an area of opportunity for further research in terms of the medium and long-term effects of the synergistic use of nanomaterials and biotechnologies, the collateral effects of NMs and NPs on microorganisms, and the trophic transfer of NMs in the food chain and the effects on human health.

\section{Nanomaterials and Nanoparticles Used in Bioremediation}

As it was mentioned, several NMs have been successfully used for the bioremediation of contaminated systems and to remove several contaminants under different conditions. Herein, we present a summary of the types of NMs with the best efficiencies during the degradation of pollutants (Table 1); in the table are also mentioned the organisms or biological systems used in the experiments. The removal performance of these NMs was measured under laboratory conditions due to the current restrictions for applying these treatments in the field; some remarks regarding the regulatory frame for their field application are done in Section 6. 
Table 1. Removal of pollutants mediated by nanoparticles and bio-based treatments.

\begin{tabular}{|c|c|c|c|c|c|c|}
\hline $\begin{array}{c}\text { Type of } \\
\text { Nanomaterial }\end{array}$ & $\begin{array}{l}\text { Organisms or Biological } \\
\text { Systems Used }\end{array}$ & Chemical Presentation & $\begin{array}{l}\text { System Where It } \\
\text { Was Used }\end{array}$ & Pollutants Degraded & Removal Efficiency & Reference \\
\hline Nanocrystals & $\begin{array}{l}\text { Enzymatic degradation by } \\
\text { bacterially overexpressed } \\
\text { organophosphorus hydrolase }\end{array}$ & Zinc sulfide (ZnS) & Water & P-nitrophenol and acid orange 7 & $>80 \%$ & [40] \\
\hline Nanoparticles & Sphingomonas sp. & $\begin{array}{l}\text { Nanoscale zero-valent iron } \\
(\mathrm{nZVI}) ; \mathrm{Ti}, \mathrm{Mn}, \mathrm{Ag}, \mathrm{Au}\end{array}$ & Water & $\begin{array}{l}\text { Decarbominated diphenyl ether; } \\
\text { chlorinated hydrocarbons, pathogens }\end{array}$ & $\begin{array}{l}67 \% \text { for diphenyl ether; } \\
>76.8 \% \text { for chlorinated } \\
\text { hydrocarbons }\end{array}$ & [41] \\
\hline Nanopowders & Soil microorganisms & Iron oxide nanopowder & Water & Azo dye direct red 23. & $98 \%$ & [42] \\
\hline Nanomembranes & $\begin{array}{l}\text { A biological extract of } \\
\text { Cynomorium coccineum } \mathrm{L} \text {. }\end{array}$ & $\begin{array}{l}\text { Thin film composite } \\
\text { polyamide }\end{array}$ & Industrial wastewater & Cyanide compounds & $\sim 20 \%$ & [32] \\
\hline Nanocomposites & Arthrobacter globiformis D47 & $\begin{array}{l}\text { Microorganism-immobilized } \\
\text { nanocellulose composites }\end{array}$ & Water & Herbicide (diuron) & $>90 \%$ & [43] \\
\hline Nanotubes & $\begin{array}{l}\text { enzyme organophosphate } \\
\text { hydrolase-MWNT paper }\end{array}$ & $\begin{array}{l}\text { Unzipped carbon nanotube } \\
\text { (CNT), single-walled CNT, } \\
\text { and multi-walled CNT }\end{array}$ & Water and Soil & Organophosphates and heavy metals & $\sim 22 \%$ & {$[44,45]$} \\
\hline Nano sponge & $\begin{array}{l}\text { two organo-clays (Dellite 67G } \\
\text { and Dellite } 43 \text { B) }\end{array}$ & $\begin{array}{l}\text { Cyclodextrin-based, highly } \\
\text { cross-linked polymers }\end{array}$ & Soil & $\begin{array}{c}\text { Triclopyr } \\
(3,5,6-\text { Trichloro-2-pyridinyloxyacetic acid) }\end{array}$ & $92 \%$ & [46] \\
\hline
\end{tabular}


Different NMs have been tested to determine their potential in reducing contaminants with the aid of living organisms. Further criteria may be applied for more specificity such as (a) nano iron and its derivatives; (b) dendrimers; (c) carbon-based NMs; (d) single-enzyme NPs; (e) engineered polymeric; (f) biogenic uraninite; and (g) metals other than iron [5]. The selection of the type of NM would depend upon the nature of the contaminant. For example, magnetite, a nano iron material is used to separate heavy metals in soils or water through its magnetic properties. Besides, carbon-based NMs are used to trap organic pollutants or heavy metals from water, soil or air.

As previously mentioned, the type of organism is also important. Plants display certain advantages over microbial organisms. For example, they produce several molecules that are involved in the transformation of pollutants. These include glutathione [47], flavonoids [48], reactive oxygen species [49] and bioactive molecules that act as a response under stress [50]. Besides, plants are easier to cultivate and handle than other organisms that need continuous nutrient supply as well as more controlled conditions.

It is important to take into consideration that NPs not only aid in the remediation process. They also serve for the detection of contaminants and, in consequence, for pollution prevention.

\section{Biological Response during the Combined Application of Nanomaterials and Bioremediation}

Bioremediation studies have demonstrated that bacteria and plants are capable of immobilizing metals and transforming both organic and inorganic contaminants. During recent years, there have been promising positive results of the combined use of NMs and bioremediation technologies to eliminate contaminants from the environment.

Table 2 shows relevant experiments where this novel approach was used.

Table 2. Successful cases of bioremediation based on nanobiotechnologies.

\begin{tabular}{|c|c|c|}
\hline Treatment & Brief Description of the Achievement & Reference \\
\hline $\begin{array}{l}\text { Hybrid treatment method using } \\
\text { nZVI-Sphingomonas sp. PH-07 }\end{array}$ & $\begin{array}{l}\text { Effective for degradation of PBDEs through } \\
\text { reductive debromination followed by } \\
\text { biological oxidation. This method may lead } \\
\text { to a remediation strategy for highly } \\
\text { halogenated environmental pollutants. }\end{array}$ & {$[41]$} \\
\hline $\begin{array}{l}\text { Rhodococcus rhodochrous DSM6263 } \\
\text { and } \mathrm{Fe}_{3} \mathrm{O}_{4} \mathrm{NP}\end{array}$ & $\begin{array}{l}\text { Given the much easier separation by } \\
\text { a magnetic field and high degradation } \\
\text { efficiency, this study provided a promising } \\
\text { technique for improving biocatalysts for } \\
\text { chlorophenols in wastewater. }\end{array}$ & [51] \\
\hline $\begin{array}{l}\text { nZVI, and nZVI combination with } \\
\text { a second metal or microorganisms }\end{array}$ & $\begin{array}{l}\text { There is a high remediation efficiency } \\
(78-99 \%) \text { of PCB with rapid reaction time. }\end{array}$ & {$[52]$} \\
\hline $\begin{array}{l}\text { Bimetallic iron-based NPs } \\
\text { and tobacco plants. }\end{array}$ & $\begin{array}{l}27 \% \text { of the total hexabromocyclododecane } \\
\text { (HBCD) was removed from polluted soil. }\end{array}$ & [53] \\
\hline $\begin{array}{l}\text { Polyvinylpyrrolidone (PVP)-coated iron } \\
\text { oxide NPs and Halomonas sp. }\end{array}$ & $\begin{array}{l}\text { The combined approach improved metal } \\
\text { removal and shortened metal remediation } \\
\text { times (approx. } 100 \% \text { removal of } \mathrm{Pb} \text { after } \\
24 \mathrm{~h} \text {, of } \mathrm{Cd} \text { after } 48 \mathrm{~h} \text { ). }\end{array}$ & [54] \\
\hline
\end{tabular}

It is important to mention that living organisms respond in a different way, according to the environmental conditions, type of contaminant and NM used. The application of NMs in bioremediation processes can be executed simultaneously or in a separated way, for instance, Kim et al. [41] evaluated the effect of a sequential nano-bio treatment using nZVI and diphenyl ether in combinations with bacteria Sphingomonas sp. PH-07 in the degradation of polybrominated diphenyl ethers (PBDEs). They found that PH-07 was able to grow in nZVI concentrations up to a high concentration of $5 \mathrm{~g} \mathrm{~L}^{-1}$ and participate in the biodegradation of PBDEs and other prospective metabolites. Moreover, the combination of nZVI nanomaterials with electrokinetic remediation, chemical oxidation, and bioremediation has been helpful in the remediation of heavily polluted sites [55]. They discussed a two-step treatment 
consisting of nZVI-aided dechlorination followed by biosurfactant-enhanced soil washing technology to remove polychlorinated biphenyls (PCBs) from soil contaminated by a transformer oil. It was found that besides direct dechlorination, nZVI greatly enhanced the soil washing efficiency by reducing the interfacial tension between the oil and soil phases, and 90\% of PCBs were removed. The combination of surfactants, electrokinetic treatments, or nZVI has been used as pretreatment in the bioremediation of nitrate anions, heavy metals, pesticides, polychlorinated biphenyls (PCBs), chlorinated volatile organic compounds (cVOCs), and radionuclides [56,57]. However, natural organic matter (NOM) such as fulvic and humic acids affect nZVI reactivity towards pollutants because of the competition between NOM and pollutants for the surface reactive sites on $\mathrm{ZVVI}$ where the reaction occurs.

Other toxic compounds, such as polychlorinated byphenils (PCBs), represent a global environmental problem because of their persistence, long-range atmospheric transport, difficult and slow degradation, and bioaccumulation. NPs catalyzed Fenton or Fenton-like, and persulfate activation can provide some useful technologies for the nanobioremediation of PCB-polluted soils. Le et al. [58] developed a nano/bio treatment for the dehalogenation of Aroclor 1248 using the bimetallic nanoparticles Pd/nFe and Burkholderia xenovorans LB400. The dehalogenation efficiencies of tri-, tetra-, penta-, and hexachlorinated biphenyls were $99 \%, 92 \%, 84 \%$, and $28 \%$, respectively. Therefore, the toxicity of the residual PCBs in terms of toxic equivalent values decreased from $33.8 \times 10^{-5}$ to $9.5 \times$ $10^{-5} \mu \mathrm{g} / \mathrm{g}$ after the integrated remediation system. These degradation rates are similar to those reported by other authors $[52,55]$. However, it has been stated that NMs do not provide any benefit in the context of bioaugmentation, since they inhibit the microbial population in polluted environments [59,60]. It has to be stated that NMs could decrease the diversity and abundance of microbial communities in soil or water but, after some days, these characteristics are recovered. Besides, NMs could also reduce the concentration of enzymes involved in ecological processes, but these increased again after the first days of the experiments. It suggests that NMs have a priming effect at the onset of the studies, but the ecological balance comes back again after some days due to their resilience.

Nevertheless, new evidences are emerging using carbon nanotubes (CNT) and Arthrobacter sp. to degrade PCBs. Pereira et al. [61] conducted a natural dye decolorisation, using CNT as redox mediators on anaerobic dye reduction. It was demonstrated that the batch reactor with CNT had the highest biodegradation rate as compared to other carbon nanomaterials.

However, it has been stated that high CNT concentrations reduced the biodegradation rate by inhibiting bacterial growth and microbial activity, while low CNT concentrations increased the biodegradation rate by stimulating bacterial growth and the overexpression of degradation genes [62]. The use of NM could mitigate the limitations regarding immobilization and entrapment of microorganisms during bioaugmentation strategies because of the large surface area [59]. Hou et al. [51] tested the biodegradation of chlorophenol in a 100-mL batch reactor using Rhodococcus rhodochrous immobilized in magnetic NPs. The cells were immobilized by using k-carrageenan and $\mathrm{Fe}_{3} \mathrm{O}_{4} \mathrm{NPs}_{\text {and }}$ it was proved that they were able to degrade 2-chlorophenol, 4-chlorophenol, 2,3-dichlorophenol and their mixture; these cells performed 30\% higher removal efficiency compared to free cells. Although the use of NM for bioaugmentation purposes is still in an early stage, the above-reviewed research mostly based on laboratory scale highlights the potential of nanotechnology for this technique. On the other hand, it should be noted that most of the NM utilized for enhanced adsorption are metals that may pose human or environmental health risks in the long run [63].

The combined effect of phyto- and nanoremediation was tested by Le et al. [53] when comparing the removal efficiency of hexabromocyclododecane in both soil and water. Bimetallic iron-based nanoparticles were used to evaluate their degradative action on HBCF. The effect on humic acids (HAs) and tobacco plants was determined as well.

It was observed that the $99 \%$ of the total $\mathrm{HBCD}(15 \mathrm{mM})$ was transformed by $\mathrm{Pd} / \mathrm{nFe}(1 \mathrm{~g} / \mathrm{L})$ within $9 \mathrm{~h}$ of treatment; when HAs were added to the aqueous solution, the removal of the contaminant was increased. In the soil system, the treatments consisted of plant only, plant with HAs, plant with 
NPs and, plant with HAs and NPs, obtaining 13\%, 15\%, 41\% and 27\% HBCD removal, respectively, compared to the HBCD removal in an unplanted soil.

The 221-298 ng/g of HBCD were detected inside the plant after treatment and the authors concluded that HAs influenced the bioaccumulation in plants; according to Tejeda et al., the HAs can accelerate the degradation of organic pollutants by increasing their solubility and enhancing their diffusive mass transfer, promoting their bioavailability to microorganisms. HAs can also act as an electron transfer mediator in the chemical reduction of organic pollutants [64], therefore the humic acids would be a good supplement for bioremediation of polluted soils.

In a seminal work, Cao et al. [54] demonstrated that polyvinylpyrrolidone-coated iron oxide NPs were beneficial for the removal of metals i.e., $\mathrm{Cd}$ (II) and $\mathrm{Pb}$ (II) by interaction with the Gram-negative bacteria Halomonas sp. The treatments consisted in a combined approach involving bacteria and NPs, bacteria only, and NPs only.

The results showed that for the combined approach, $100 \%$ of the $\mathrm{Cd}$ originally aggregated was removed after $24 \mathrm{~h}$ and the same percentage of $\mathrm{Cd}$ was eliminated after $48 \mathrm{~h}$. For the treatments with $\mathrm{Ns}$ only, the removal of $60 \%$ and $80 \%$ for $\mathrm{Cd}$ and $\mathrm{Pb}$, respectively, was observed. When the metal removal in the presence of Halomonas sp. only was estimated, the removal of Cd increased to $80 \%$, contrarily to the same treatment for $\mathrm{Pb}$, where the same removal as that for NPs was observed i.e., $80 \%$.

$\mathrm{Cd}, \mathrm{Pb}$ and $\mathrm{Fe}$ (from NPs) were analyzed in the following bacterial components: extra polymeric substances (EPS), and it was observed that EPS was most important in metal removal, and that there was a significant promotion of $\mathrm{Cd}$ intracellular transportation, but not $\mathrm{Pb}$, by $\mathrm{NPs}$. A reduced $\mathrm{Pb}$ internalization was identified that may have resulted from EPS acting as an uptake barrier coupled with an effective efflux system of Halomonas sp. as a resistance mechanism. Besides the beneficial effects of this combined approach, the authors suggested further and more pointed investigation.

Kumari and Singh [22] demonstrated that NMs are useful as facilitators in the bioremediation of pollutants either by enhancing microbial growth, immobilizing remediating agents or through induced production of remediating microbial enzymes. In a similar study it was demonstrated that NMs induced the production of microbial biosurfactants, improving contaminant solubility and thereby generating a conducive environment for the bioremediation of these compounds [65]. These NMs-biosurfactant interactions could be used trough biostimulation techniques i.e., nanobiostimulation techniques. It has to be stated that biostimulation techniques have the potential to efficiently dissipate pollutants from soil or water under eco-friendly, fast, and inexpensive procedures.

Besides, iron oxide NPs coated with polyvinylpyrrolidone (PVP) were used in the bioremediation of sediments from a contaminated river using bacteria of the genus Halomonas [66]. They also demonstrated that PVP was effective in transforming labile $\mathrm{Cd}$ and $\mathrm{Pb}$ to stable fractions, with the decrease of the mobility of metals. Besides, urease and catalase activities were enhanced showing certain degrees of recovery in sediment metabolic functions.

Torres-Martínez et al. [40] explained four steps in the mechanisms of degradation of p-nitrophenol (pNP) using ZnS nanocrystals in water. The first part is the excitation of the glutathione (GSH)- or L-cysteine (Cys)-ZnS nanocrystals with bandgap energy irradiation leading to charge separation, the promotion of electrons into the conduction band, and the formation of positive holes in the valence band. The second step involves the migration of electron-hole pairs to the surface of the nanocrystals, which is facilitated by the small particle size. The third step is the formation of highly reactive hydroxyl radicals in aqueous medium. The fourth and last part is the ring-opening caused by a nonspecific reaction of the hydroxyl radicals with the double-bond structures of pNP.

Hou et al. [51] described the mechanisms involved in the degradation of chlorophenols in a batch reactor using $R$. rhodochrous DSM6263 immobilized in k-carrageenan with magnetic NPs. The first step was the hydroxylation at the ortho positions of the chlorophenolic rings, which formed chlorocatechols. DSM6263 strain biodegraded CPs via the constitutively expressed enzymes [51], and degraded aniline and phenol to catechol via the $\beta$-ketoadipate pathway. However, no further metabolization of cis, cis-muconic acid occurred. It has been proven that different microbial strains can naturally degrade the 
same pollutants through different ways, such as Rhodococcus sp. AN-22 by using the phenol metabolic pathway, integrated by CatA (catechol 1,2-dioxygenase), CatB (cis, cis-muconate cycloisomerase) and CatC (muconolactone isomerase) to degrade aniline [67].

Pereira et al. [61] performed experiments where the effect of carbon-based materials (CBM) as a redox mediator on dye biodegradation was evaluated. CNT were used to evaluate the biodegradation kinetics of the anaerobic discoloration of different classes of azo dyes including acid (AO10), mordant (MY10), and reactive (RR120). It is worth mentioning that the anaerobic color removal rate is related to the number of azo bonds in the dye molecule, while the reduction rates are affected by changes in electron density in the azo group region. Therefore, the substitution of electron-withdrawing groups $\left(-\mathrm{SO}_{3} \mathrm{H},-\mathrm{SO}_{2} \mathrm{NH}_{2}\right)$ in the para position of the phenyl ring concerning the azo bond, improves the reduction rate. On the other hand, electron-withdrawing groups $\left(-\mathrm{OH}\right.$ and $\left.-\mathrm{NH}_{2}\right)$ decrease the electron density close to the azo bond, making possible the reduction process. Besides, hydrogen bonding has a significant effect on the rate of reduction in the region of the azo bond [68]. Color removal was associated with the azo bond cleavage. The final products were sulfanilic acid (SA) and 5-aminosalicylic acid (5-ASA), as witnessed by high-performance liquid chromatography (HPLC). These compounds were biodegraded under aerobic conditions via the enrichment cultures during the batch experiment [69].

Various types of NPs are being used to increase the microbial degradation of pollutants [22]. However, avoiding the unintentional release of NPs in the environment is very crucial for maintaining a sustainable ecosystem. Further research on bioaccumulators and toxicokinetics of NP must be executed to prevent adverse effects on flora and fauna [22].

\section{Current and Future Development of Environmental Nanoapplications Based on Molecular Biotechnology}

In addition to the mentioned nanotechnology applications in environmental biotechnology, innovations may emerge from other fields of nanotechnology that move at a faster pace, for example, medical nanotechnology.

Nanostructure functionalization with biomolecules is an area worth exploring. This approach has been tested with state-of-the-art experimental designs inspired by natural molecular phenomena. For example, in [70] were designed membranes harboring amyloid proteins and activated porous carbon for heavy-metals removal/recovery. Inspired by the detrimental amyloid protein formation in neurons, these authors changed the tertiary structure of milk proteins to create amyloid fibrils capable of capturing different ions by the cysteine moieties. This research highlighted the importance of finding a cheap source of biomolecules as a key to this type of development. Additionally, natural proteins display several advantages. For example, they can be produced through well-established recombinant technologies in a cost-effective manner and can harbor 20 different amino acids that provide a large combinatorial capacity to interact with other molecules, as well as create new catalytic surfaces and structures [71].

Biotechnology can also help to provide ecofriendly methodologies for NPs functionalization. Gao et al. [72] have recently introduced the bacteria Komagataeibacter sucrofermentans in the biological toolbox to produce novel cellulose-like polymers functionalized with custom moieties. These bacteria are cultured with traditional bioreactor methodologies and fed with glucose monomers ornamented with the desired chemical modifications resulting in their biological incorporation in the polymer. This strategy bypasses the use of complex solvents, stoichiometry, and the production of environmentally dangerous residues. The optimization of this biosystem by classic and next-generation biotechnological modifications (mutagenesis, protein engineering or gene editing) holds a great potential to simplify the synthesis of a large amount of cellulose-based NMs with several applications [73].

Recent developments in the field of RNA-based fungicides indicate that it is a feasible technology for substituting traditional biochemical fungicides. Double-strand RNAs, designed to hybridize with vital mRNAs of fungal pathogens, are sprayed on leaves or fruits and induce expression silencing in 
the pathogen [74]. However, the short mean-life of naked RNAs in the environment is an obstacle to overcome [74]. Traditional clay nanosheets were tested as protectants of double-strand RNA and probed to enhance the mean-life of the biomolecules and extend the biocidal actions against the fungal pathogen [75]. Although this technology was created for the protection of aerial plant organs, it has recently been applied in root protection. Chariou et al. [76] tested several nanoscale encapsulated architectures that ranged from traditional silica particles to recombinant or plant-produced virus capsules. The proof-of-concept was carried out with a nematicide and the biologically derived capsules proved superior in soil penetration and cargo release. These bionanoparticles are biodegradable and leave behind no organic pollution, truly earning the label of ecofriendly. It is expected that this field will highly benefit from next-generation NPs biofunctionalization.

The 3D construction of DNA structures through DNA hybridization constitutes a frontier research area largely unexplored in environmental biotechnology. The relatively simple, yet malleable, rules of recognition between nucleotides of different strands of DNA can be applied to build several geometric arrangements ("molecular origami"), from simple crossover tiles up to polyhedral meshes [77]. These architectures provide a new toolbox for functionalization, as illustrated by the work of DNA nanorobots that can be loaded with intractable molecules (other DNAs/RNAs or proteins) that serve as cargo, fasteners or springs. In [78] is described the design of DNA sheets that interact with the protein thrombin that becomes compartmentalized when other DNA molecules seal the nanosheet, acting as fasteners. The DNA origami, now turned into a nanotube, will only open when a key is found, in this case a tumor-produced protein named nucleolin, releasing the thrombin cargo and inducing coagulation and necrosis of the tumor. This development demonstrated the programmable and complex mechanics that biomolecular-based biorobots could achieve. Although this is a development aimed at biomedicine, it provides an outstanding example of biomolecular interactions that can be extended to environmental applications like next-generation pesticides or the elimination of antibiotic-resistant super-bacteria.

A concern of DNA origami arrangements is cost. Recently, in [77] were reviewed biotechnological options to reach the economic feasibility of DNA/RNA production such as chip synthesis, recombinant bacteria and naturally occurring bacteria able to export RNAs.

Another example of sophisticated codification of nanotechnology to obtain remote information is the work of Koman et al. [79], where a decision diagram was chemically coded with inorganic molecules to detect and irreversibly inform the presence of analytes in the air, such as soot, ammonia and triethylamine. Other inorganic sensors have been developed to trace abiotic particles, like nanoplastics [80]; this concept can be extended to incorporate biomolecules to follow the path of cells in wastewater facilities, or immunedetectable pollutants, tasks currently performed by costly and complicated assays like DNA sequencing and HPLC. Inorganic sensors can also code their self-precipitation through photoinduction and ion changes in their environment [81]; in biology, several proteins have more versatile photoresponsive characteristics that provide materials with novel capabilities, for example, CarH bacterial transcription factor [82] or plant/fungal LOV domains [83].

Molecular biotechnology has also been proposed for large-scale applications such as water desalination. More than a decade ago, Kumar et al. [84] tested the incorporation of the bacterial protein aquaporin $\mathrm{Z}$ into polymeric membranes and demonstrated that it could exclude salt and yield purified water. With modern protein modeling algorithms and molecular biology techniques, this approach was optimized to produce porin proteins with enhanced exclusion activities for both organic and inorganic water solutes [85]. An emerging field is the technological use of oxygen-sensitive proteins present in humans and plants to develop $\mathrm{O}_{2}$ biosensors and inducible genetic circuits; originally thought to be for in vivo applications, they can be adapted to prepare functional NMs able to stoichiometrically respond to $\mathrm{O}_{2}$ levels [86]. These concepts, explored with proteins, have also been demonstrated with DNA molecules able to exclude complex analytes such as proteins and open a wide area of sensing and purification opportunities [87]. Recently, Ryu et al. [88] and Álvarez et al. [89] reviewed the field of transmembrane proteins incorporated into membranes and their coupling to different transductors and applications in gas monitoring, pesticide detection, microarrays, and energy harvesting. 
In the future, enzymes may be incorporated in the above-discussed arrangements to monitor more complex pollutants or their combinations. This concept is used in healthcare monitoring where biosensors have been fixed in a plethora of materials like patches, temporary tattoos or wrists, among others [90]. It should be noticed that the large economic market of diabetes management drives these innovations. However, the protection of workers doing dangerous tasks in radioactive, potentially toxic, or enclosed areas can benefit from the development of real-time monitoring bionanotechnologies.

\section{International Markets and Regulations of Nanotechnologies Applied in Bioremediation}

Nanotechnologies used in bioremediation processes are expected to drive the technological evolution for the improvement of the environmental quality in developed and emerging countries [91,92]. A significant amount of research has been performed to determine the mechanisms of decontamination and remediation [93].

As it has been discussed previously, the biosafety related to the use and application of nanomaterials is a high concern due to the lack of knowledge and validated protocols to measure the impact of these materials on human health, loss of biodiversity [94] and bioaccumulation [95], and transport of NMs in trophic chains [96]. Diverse international institutions such as USEPA, European Observatory for Nanomaterials (EON), the OECD Working Party on Manufactured Nanomaterials (WPMN) and ISO Technical Committee TC 229 "Nanotechnologies" have established international cooperation in order to increase the application of available regulations $[97,98]$.

Furthermore, nanotechnology and bioremediation world markets are expected to continue growing and developing new niches to improve not only environmental aspects but also human lifestyle [99].

The global nanotechnology market is expected to exceed US $\$ 125$ billion by 2024; this sector continues to have an impact on other markets, fundamentally in electronics, energy, biomedical, cosmetics, defense, energy and agriculture [100] and, according to the US-EPA it is estimated that bioremediation and phytoremediation technologies could have an annual growth of US\$1.5 billion per year [101]. The development of new methodologies and incorporation of nanotechnologies will expand new opportunities for treating sewage, lakes, rivers, and ponds, among others, creating new consumers and strengthening world trade [102].

\section{Conclusions}

The synergy between NPs and microorganisms for the degradation of some contaminants has been proven in batch experiments, however, there is still a lack of knowledge about the synergetic effect of nanoparticles and biotechnologies during a nanobioremediation process and how these combined technologies respond to contaminants of a diverse nature. It should be noted that, to the best of our knowledge, no safety data on the long-term use of NPs with microorganisms has been provided. Bionanoparticles present various advantages over metallic NPs, such as their biodegradability producing less impact on the environment. Current nanotechnologies could be used in remediation processes for decontaminating soil, air, or water, but, more cost-effective methods of production should arise.

An important issue concerning the use of these types of materials is the regulatory framework. Scientists could contribute to the understanding of the interactions of NMs and bio-based technologies during remediation processes under variable environmental conditions and, as a consequence, offer arguments for better regulation.

Finally, nanobioremediation might enormously contribute to sustainability because it offers environmental advantages and is cheap when compared to other technologies; even more the range of applications of NMs, coupled with biological treatments, has demonstrated high effectivity in the degradation of contaminants, which provides new possibilities to face environmental challenges.

Author Contributions: All authors contributed to planning and writing the paper. All authors have read and agreed to the published version of the manuscript. 
Funding: J.M.P.-C. thanks CONACYT-CB for financially supporting this research (Grant 287137).

Acknowledgments: E.V.-N. and C.E.M.-G. thank the Universidad de Guanajuato for all the support and facilities to develop this work. E.V.-N. thanks especially the support of BVF for her patient technical support during the preparation of this manuscript.

Conflicts of Interest: The authors declare no conflict of interest.

\section{References}

1. Wuana, R.A.; Okieimen, F.E. Heavy Metals in Contaminated Soils: A Review of Sources, Chemistry, Risks and Best Available Strategies for Remediation. ISRN Ecol. 2011, 1, 1-20. [CrossRef]

2. Azubuike, C.C.; Chikere, C.B.; Okpokwasili, G.C. Bioremediation techniques-classification based on site of application: Principles, advantages, limitations and prospects. World J. Microbiol. Biotechnol. 2016, 32, 180. [CrossRef] [PubMed]

3. Tanzadeh, J.; Ghasemi, M.F.; Anvari, M.; Issazadeh, K. Biological removal of crude oil with the use of native bacterial consortia isolated from the shorelines of the Caspian Sea. Biotechnol. Biotechnol. Equip. 2020, 34, 361-374. [CrossRef]

4. Mapelli, F.; Scoma, A.; Michoud, G.; Aulenta, F.; Boon, N.; Borin, S.; Kalogerakis, N.; Daffonchio, D. Biotechnologies for Marine Oil Spill Cleanup: Indissoluble Ties with Microorganisms. Trends Biotechnol. 2017, 35, 860-870. [CrossRef] [PubMed]

5. Rizwan, M.D.; Singh, M.; Mitra, C.K.; Morve, R.K. Ecofriendly Application of Nanomaterials: Nanobioremediation. J. Nanopart. 2014, 1, 1-7. [CrossRef]

6. Yogalakshmi, K.N.; Das, A.; Rani, G.; Jaswal, V.; Randhawa, J.S. Nano-bioremediation: A New Age Technology for the Treatment of Dyes in Textile Effluents. In Bioremediation of Industrial Waste for Environmental Safety; Springer: Singapore, 2020.

7. De Gisi, S.; Minetto, D.; Lofrano, G.; Libralato, G.; Conte, B.; Todaro, F.; Notarnicola, M. Nano-scale Zero Valent Iron (nZVI) treatment of marine sediments slightly polluted by heavy metals. Chem. Eng. Trans. 2017, 60, 139-144.

8. Bharagava, R.N.; Saxena, G.; Mulla, S.I. Introduction to Industrial Wastes Containing Organic and Inorganic Pollutants and Bioremediation Approaches for Environmental Management. In Bioremediation of Industrial Waste for Environmental Safety; Springer: Singapore, 2020.

9. Cecchin, I.; Reddy, K.R.; Thomé, A.; Tessaro, E.F.; Schnaid, F. Nanobioremediation: Integration of nanoparticles and bioremediation for sustainable remediation of chlorinated organic contaminants in soils. Int. Biodeterior. Biodegrad. 2017, 119, 419-428. [CrossRef]

10. Avio, C.G.; Gorbi, S.; Regoli, F. Plastics and microplastics in the oceans: From emerging pollutants to emerged threat. Mar. Environ. Res. 2017, 128, 2-11. [CrossRef]

11. Alimi, O.S.; Farner Budarz, J.; Hernandez, L.M.; Tufenkji, N. Microplastics and nanoplastics in aquatic environments: Aggregation, deposition, and enhanced contaminant transport. Environ. Sci. Technol. 2018, 52, 1704-1724. [CrossRef]

12. Sousa, J.C.G.; Ribeiro, A.R.; Barbosa, M.O.; Pereira, M.F.R.; Silva, A.M.T. A review on environmental monitoring of water organic pollutants identified by EU guidelines. J. Hazard. Mater. 2018, 344, 146-162. [CrossRef]

13. Thompson, L.A.; Darwish, W.S. Environmental chemical contaminants in food: Review of a global problem. J. Toxicol. 2019. [CrossRef] [PubMed]

14. Jeon, J.R.; Murugesan, K.; Baldrian, P.; Schmidt, S.; Chang, Y.S. Aerobic bacterial catabolism of persistent organic pollutants-Potential impact of biotic and abiotic interaction. Curr. Opin. Biotech. 2016, 38, 71-78. [CrossRef] [PubMed]

15. Zhu, X.; Chen, B.; Zhu, L.; Xing, B. Effects and mechanisms of biochar-microbe interactions in soil improvement and pollution remediation: A review. Environ. Pollut. 2017, 227, 98-115. [CrossRef] [PubMed]

16. Hurtado, C.; Montano-Chávez, Y.N.; Domínguez, C.; Bayona, J.M. Degradation of emerging organic contaminants in an agricultural soil: Decoupling biotic and abiotic processes. Water Air Soil Pollut. 2017, 228, 243. [CrossRef]

17. Kang, J.W. Removing environmental organic pollutants with bioremediation and phytoremediation. Biotechnol. Lett. 2014, 36, 1129-1139. [CrossRef] 
18. Fulekar, M.H.; Pathak, B. Environmental Nanotechnology, 1st ed.; CRC Press: Boca Raton, FL, USA, 2017; pp. 140-157.

19. Kuppusamy, S.; Thavamani, P.; Venkateswarlu, K.; Lee, Y.B.; Naidu, R.; Megharaj, M. Remediation approaches for polycyclic aromatic hydrocarbons (PAHs) contaminated soils: Technological constraints, emerging trends and future directions. Chemosphere 2017, 168, 944-968. [CrossRef]

20. Srivastava, S.; Shukla, A. Emerging aspects of bioremediation of arsenic. In Green Technologies and Environmental Sustainability, 1st ed.; Singh, R., Kumar, S., Eds.; Springer: Cham, Switzerland, 2017; Volume 1, pp. 395-407.

21. Fernández, P.M.; Viñarta, S.C.; Bernal, A.R.; Cruz, E.L.; Figueroa, L.I.C. Bioremediation strategies for chromium removal: Current research, scale-up approach and future perspectives. Chemosphere 2018, 208, 139-148. [CrossRef]

22. Kumari, B.; Singh, D.P. A review on multifaceted application of nanoparticles in the field of bioremediation of petroleum hydrocarbons. Ecol. Eng. 2016, 97, 98-105. [CrossRef]

23. Koul, B.; Taak, P. Chemical methods for soil remediation. In Biotechnological Strategies for Effective Remediation of Polluted Soils, 1st ed.; Koul, B., Taak, P., Eds.; Springer: Singapore, 2018; Volume 1, pp. 77-84.

24. El-Ramady, H.; Alshaal, T.; Abowaly, M.; Abdalla, N.; Taha, H.S.; Al-Saeedi, A.H.; Shalaby, T.; Amer, M.; Fári, M.; Domokos-Szabolcsy, É.; et al. Nanoremediation for Sustainable Crop Production. In Nanoscience in Food and agriculture, 1st ed.; Ranjan, S., Dasgupta, N., Lichtfouse, E., Eds.; Springer: Singapore, 2017; Volume 1, pp. 335-363.

25. Tan, W.; Peralta-Videa, J.R.; Gardea-Torresdey, J.L. Interaction of titanium dioxide nanoparticles with soil components and plants: Current knowledge and future research needs-a critical review. Environ. Sci. Nano 2018, 5, 257-278. [CrossRef]

26. Wang, A.; Ng, H.P.; Xu, Y.; Li, Y.; Zheng, Y.; Yu, J.; Han, F.; Peng, F.; Fu, L. Gold nanoparticles: Synthesis, stability test, and application for the rice growth. J. Nanomater. 2014, 1,1-6. [CrossRef]

27. Tang, H.; Chen, X.; Niu, Y.W.; Luo, X.; Wang, Z.; Chen, M.; Shi, G. Thermal stability characteristics of in situ nano-particles formed in metal melt. Mater. Lett. 2016, 162, 261-264. [CrossRef]

28. Taylor, A.; Wilson, K.M.; Murray, P.; Fernig, D.G.; Lévy, R. Long-term tracking of cells using inorganic nanoparticles as contrast agents: Are we there yet? Chem. Soc. Rev. 2012, 41, 2707-2717. [CrossRef] [PubMed]

29. Vieira, R.H.S.F.; Volesky, B. Biosorption: A solution to pollution? Int. Microbiol. 2000, 3, 17-24.

30. Hu, Z.G.; Zhang, J.; Chan, W.L.; Szeto, Y.S. The sorption of acid dye onto chitosan nanoparticles. Polymer 2006, 47, 5338-5842. [CrossRef]

31. Wang, Y.; Morin, G.; Ona-Nguema, G.; Juillot, F.; Calas, G.; Brown, G.E. Distinctive arsenic(V) trapping modes by magnetite nanoparticles induced by different sorption processes. Environ. Sci. Technol. 2011, 45, 7258-7266. [CrossRef]

32. Sebeia, N.; Jabli, M.; Ghith, A.; Saleh, T.A. Eco-friendly synthesis of Cynomorium coccineum extract for controlled production of copper nanoparticles for sorption of methylene blue dye. Arab. J. Chem. 2019, 13, 4263-4274. [CrossRef]

33. Pathak, P.D.; Mandavgane, S.A.; Kulkarni, B.D. Fruit peel waste as a novel low-cost bio adsorbent. Rev. Chem. Eng. 2015. [CrossRef]

34. Matouq, M.; Jildeh, N.; Qtaishat, M.; Hindiyeh, M.; Al Syouf, M.Q. The adsorption kinetics and modeling for heavy metals removal from wastewater by Moringa pods. J. Environ. Chem. Eng. 2015, 31, 361-381. [CrossRef]

35. Dada, A.O.; Ojediran, J.O.; Olalekan, A.P. Sorption of Pb2+ from aqueous solution unto modified rice husk: Isotherms studies. Adv. Phys. Chem. 2013, 1, 1-6. [CrossRef]

36. Olalekan, A.P.; Dada, A.O.; Okewale, A.O. Comparative adsorption isotherm study of the removal of $\mathrm{Pb} 2+$ and Zn2+ onto agricultural waste. Res. J. Chem. Environ. Sci. 2013, 1, 22-7. [CrossRef]

37. Peixoto, R.S.; Vermelho, A.B.; Rosado, A.S. Petroleum-degrading enzymes: Bioremediation and new prospects. Enzyme Res. 2011, 1, 1-7. [CrossRef]

38. Sohail, M.I.; Waris, A.A.; Ayub, M.A.; Usman, M.; Zia ur Rehman, M.; Sabir, M.; Faiz, T. Environmental application of nanomaterials: A promise to sustainable future. In Engineered Nanomaterials and Phytonanotechnology: Challenges for Plant Sustainability, 1st ed.; Kumar, V.S., Kumar, D.A., Eds.; Elsevier: Cambridge, MA, USA, 2019; Volume 1, pp. 1-53. 
39. Ramírez-García, R.; Gohil, N.; Singh, V. Recent Advances, Challenges, and Opportunities in Bioremediation of Hazardous Materials. In Phytomanagement of Polluted Sites, 1st ed.; Chandra, P.V., Bauddh, K., Eds.; Elsevier: Cambridge, MA, USA, 2019; Volume 1, pp. 517-568.

40. Torres-Martínez, C.L.; Kho, R.; Mian, O.I.; Mehra, R.K. Efficient photocatalytic degradation of environmental pollutants with mass-produced ZnS nanocrystals. J. Colloid Interface Sci. 2001. [CrossRef] [PubMed]

41. Kim, Y.M.; Murugesan, K.; Chang, Y.Y.; Kim, E.J.; Chang, Y.S. Degradation of polybrominated diphenyl ethers by a sequential treatment with nanoscale zero valent iron and aerobic biodegradation. J. Chem. Technol. Biotechnol. 2012, 240, 525-532. [CrossRef]

42. Kos, L.; Sójka-Ledakowicz, J.; Michalska, K.; Perkowski, J. Decomposition of azo dye C.I. Direct Yellow 86 by the fenton process in the presence of nanoparticles of iron oxides. Fibres Text. East. Eur. 2014, 5, 114-120.

43. Liu, J.; Morales-Narváez, E.; Vicent, T.; Merkoçi, A.; Zhong, G.H. Microorganism-decorated nanocellulose for efficient diuron removal. Chem. Eng. J. 2018, 354, 1083-1091. [CrossRef]

44. Mechrez, G.; Krepker, M.A.; Harel, Y.; Lellouche, J.P.; Segal, E. Biocatalytic carbon nanotube paper: A "one-pot" route for fabrication of enzyme-immobilized membranes for organophosphate bioremediation. J. Mater. Chem. B 2014, 2, 915-922. [CrossRef]

45. Fosso-Kankeu, E.; Mulaba-Bafubiandi, A.F.; Mishra, A.K. Prospects for Immobilization of Microbial Sorbents on Carbon Nanotubes for Biosorption: Bioremediation of Heavy Metals Polluted Water. In Application of Nanotechnology in Water Research, 1st ed.; Mishra, A.K., Ed.; John Wiley \& Sons, Inc.: Hoboken, NJ, USA, 2014; Volume 1, pp. 213-235.

46. Baglieri, A.; Nègre, M.; Trotta, F.; Bracco, P.; Gennari, M. Organo-clays and nanosponges for acquifer bioremediation: Adsorption and degradation of triclopyr. J. Environ. Sci. Health Part B Pestic. Food Contam. Agric. Wastes 2013, 48, 784-792. [CrossRef]

47. Szalai, G.; Kellos, T.; Galiba, G.; Kocsy, G. Glutathione as an antioxidant and regulatory molecule in plants under abiotic stress conditions. J. Plant Growth Regul. 2009, 28, 66-280. [CrossRef]

48. Mierziak, J.; Kostyn, K.; Kulma, A. Flavonoids as important molecules of plant interactions with the environment. Molecules 2014, 19, 16240-16265. [CrossRef]

49. Camejo, D.; Guzmán-Cedeño, Á.; Moreno, A. Reactive oxygen species, essential molecules, during plant-pathogen interactions. Plant Physiol. Biochem. 2016, 103, 10-23. [CrossRef]

50. Franzoni, G.; Trivellini, A.; Bulgari, R.; Cocetta, G.; Ferrante, A. Bioactive Molecules as Regulatory Signals in Plant Responses to Abiotic Stresses. In Plant Signaling Molecules, 1st ed.; Khan, M.I.R., Reddy, P.S., Ferrante, A., Khan, N., Eds.; Woodhead Publishing: Duxford, UK, 2019; Volume 1, pp. 169-182.

51. Hou, J.; Liu, F.; Wu, N.; Ju, J.; Yu, B. Efficient biodegradation of chlorophenols in aqueous phase by magnetically immobilized aniline-degrading Rhodococcus rhodochrous strain. J. Nanobiotechnol. 2016, 14, 5. [CrossRef] [PubMed]

52. Jing, R.; Fusi, S.; Kjellerup, B.V. Remediation of Polychlorinated Biphenyls (PCBs) in contaminated soils and sediment: State of knowledge and perspectives. Front. Environ. Sci. 2018, 6, 79. [CrossRef]

53. Le, T.T.; Yoon, H.; Son, M.H.; Kang, Y.G.; Chang, Y.S. Treatability of hexabromocyclododecane using Pd/Fe nanoparticles in the soil-plant system: Effects of humic acids. Sci. Total Environ. 2019, 689, 444-450. [CrossRef] [PubMed]

54. Cao, X.; Alabresm, A.; Chen, Y.P.; Decho, A.W.; Lead, J. Improved metal remediation using a combined bacterial and nanoscience approach. Sci. Total Environ. 2020, 704, 135378. [CrossRef]

55. Fan, G.; Wang, Y.; Fang, G.; Zhu, X.; Zhou, D. Review of chemical and electrokinetic remediation of PCBs contaminated soils and sediments. Environ. Sci. Process. Impacts 2016, 18, 1140-1156. [CrossRef] [PubMed]

56. Bhattacharya, K.; Mukherjee, S.P.; Gallud, A.; Burkert, S.C.; Bistarelli, S.; Bellucci, S.; Bottini, M.; Star, A.; Fadeel, B. Biological interactions of carbon-based nanomaterials: From coronation to degradation. Nanomed. Nanotechnol. Biol. Med. 2016, 12, 333-351. [CrossRef] [PubMed]

57. De Lima, R.; Seabra, A.B.; Durán, N. Silver nanoparticles: A brief review of cytotoxicity and genotoxicity of chemically and biogenically synthesized nanoparticles. J. Appl. Toxicol. 2012, 32, 867-879. [CrossRef] [PubMed]

58. Le, T.T.; Nguyen, K.H.; Jeon, J.R.; Francis, A.J.; Chang, Y.S. Nano/bio treatment of polychlorinated biphenyls with evaluation of comparative toxicity. J. Hazard. Mater. 2015, 287, 335-341. [CrossRef]

59. Nzila, A.; Razzak, S.A.; Zhu, J. Bioaugmentation: An emerging strategy of industrial wastewater treatment for reuse and discharge. Int. J. Environ. Res. Public Health 2016, 13, 846. [CrossRef] 
60. Amoatey, P.; Baawain, M.S. Effects of pollution on freshwater aquatic organisms. Water Environ. Res. 2019, 91, 1272-1287. [CrossRef]

61. Pereira, R.A.; Pereira, M.F.R.; Alves, M.M.; Pereira, L. Carbon based materials as novel redox mediators for dye wastewater biodegradation. Appl. Catal. B Environ. 2014, 393, 219-226. [CrossRef]

62. Zhang, C.; Li, M.; Xu, X.; Liu, N. Effects of carbon nanotubes on atrazine biodegradation by Arthrobacter sp. J. Hazard. Mater. 2015, 287, 1-6. [CrossRef]

63. Fayemiwo, O.M.; Daramola, M.O.; Moothi, K. Btex compounds in water-Future trends and directions for water treatment. Water SA 2017, 43, 602-613. [CrossRef]

64. Li, J.; Liu, G.; Zhou, J.; Wang, A.; Wang, J.; Jin, R. Redox activity of lignite and its accelerating effects on the chemical reduction of azo dye by sulfide. RSC Adv. 2016. [CrossRef]

65. Decesaro, A.; Machado, T.S.; Cappellaro, Â.C.; Reinehr, C.O.; Thomé, A.; Colla, L.M. Biosurfactants during in situ bioremediation: Factors that influence the production and challenges in evalution. Environ. Sci. Pollut. Res. 2017, 24, 20831-20843. [CrossRef] [PubMed]

66. Xue, W.; Huang, D.; Zeng, G.; Wan, J.; Zhang, C.; Xu, R.; Cheng, M.; Deng, R. Nanoscale zero-valent iron coated with rhamnolipid as an effective stabilizer for immobilization of $\mathrm{Cd}$ and $\mathrm{Pb}$ in river sediments. J. Hazard. Mater. 2018, 341, 381-389. [CrossRef] [PubMed]

67. Matsumura, E.; Sakai, M.; Hayashi, K.; Murakami, S.; Takenaka, S.; Aoki, K. Constitutive expression of cat $\mathrm{ABC}$ genes in the aniline-assimilating bacterium Rhodococcus species AN-22: Production, purification, characterization and gene analysis of CatA, CatB and CatC. Biochem. J. 2006, 393, 219-226. [CrossRef] [PubMed]

68. Beydilli, M.I.; Pavlstathis, S.G.; Tincher, W.C. Biological decolorization of the azo dye reactive red 2 under various oxidation-reduction conditions. Water Environ. Res. 2000, 72, 698-705. [CrossRef]

69. Tan, N.C.G.; Prenafeta-Boldú, F.X.; Opsteeg, J.L.; Lettinga, G.; Field, J.A. Biodegradation of azo dyes in cocultures of anaerobic granular sludge with aerobic aromatic amine degrading enrichment cultures. Appl. Microbiol. Biotechnol. 1999, 51, 865-871. [CrossRef]

70. Bolisetty, S.; Mezzenga, R. Amyloid-carbon hybrid membranes for universal water purification. Nat. Nanotechnol. 2016, 11, 365. [CrossRef]

71. Ljubetič, A.; Lapenta, F.; Gradišar, H.; Drobnak, I.; Aupič, J.; Strmšek, Ž.; Lainšček, D.; Hafner-Bratkovič, I.; Majerle, A.; Krivec, N.; et al. Design of coiled-coil protein-origami cages that self-assemble in vitro and in vivo. Nat. Biotechnol. 2017, 35, 1094-1101. [CrossRef] [PubMed]

72. Gao, M.; Li, J.; Bao, Z.; Hu, M.; Nian, R.; Feng, D.; An, D.; Li, X.; Xian, M.; Zhang, H. A natural in situ fabrication method of functional bacterial cellulose using a microorganism. Nat. Commun. 2019, 10, 1-10. [CrossRef]

73. Sharma, A.; Thakur, M.; Bhattacharya, M.; Mandal, T.; Goswami, S. Commercial application of cellulose nano-composites-A review. Biotechnol. Rep. 2019, 21, e00316. [CrossRef] [PubMed]

74. Wang, M.; Weiberg, A.; Lin, F.M.; Thomma, B.P.H.J.; Huang, H.D.; Jin, H. Bidirectional cross-kingdom RNAi and fungal uptake of external RNAs confer plant protection. Nat. Plants 2016, 2, 1-10. [CrossRef]

75. Mitter, N.; Worrall, E.A.; Robinson, K.E.; Li, P.; Jain, R.G.; Taochy, C.; Fletcher, S.J.; Carroll, B.J.; Lu, G.Q.; $\mathrm{Xu}$, Z.P. Clay nanosheets for topical delivery of RNAi for sustained protection against plant viruses. Nat. Plants 2017, 3,1-10. [CrossRef] [PubMed]

76. Chariou, P.L.; Dogan, A.B.; Welsh, A.G.; Saidel, G.M.; Baskaran, H.; Steinmetz, N.F. Soil mobility of synthetic and virus-based model nanopesticides. Nat. Nanotechnol. 2019, 14, 712-718. [CrossRef]

77. Li, J.; Green, A.A.; Yan, H.; Fan, C. Engineering nucleic acid structures for programmable molecular circuitry and intracellular biocomputation. Nat. Chem. 2017, 9, 1056. [CrossRef] [PubMed]

78. Li, S.; Jiang, Q.; Liu, S.; Zhang, Y.; Tian, Y.; Song, C.; Wang, J.; Zou, Y.; Anderson, G.J.; Han, J.Y.; et al. A DNA nanorobot functions as a cancer therapeutic in response to a molecular trigger in vivo. Nat. Biotechnol. 2018, 36, 258. [CrossRef] [PubMed]

79. Koman, V.B.; Liu, P.; Kozawa, D.; Liu, A.T.; Cottrill, A.L.; Son, Y.; Lebron, J.A.; Strano, M.S. Colloidal nanoelectronic state machines based on 2D materials for aerosolizable electronics. Nat. Nanotechnol. 2018, 13, 819-827. [CrossRef]

80. Mitrano, D.M.; Beltzung, A.; Frehland, S.; Schmiedgruber, M.; Cingolani, A.; Schmidt, F. Synthesis of metal-doped nanoplastics and their utility to investigate fate and behaviour in complex environmental systems. Nat. Nanotechnol. 2019, 14, 362-368. [CrossRef] [PubMed] 
81. Brandl, F.; Bertrand, N.; Lima, E.M.; Langer, R. Nanoparticles with photoinduced precipitation for the extraction of pollutants from water and soil. Nat. Commun. 2015, 6, 1-10. [CrossRef]

82. Wang, R.; Yang, Z.; Luo, J.; Hsing, I.M.; Sun, F. B12-dependent photoresponsive protein hydrogels for controlled stem cell/protein release. Proc. Natl. Acad. Sci. USA 2017, 114, 5912-5917. [CrossRef] [PubMed]

83. Seifert, S.; Brakmann, S. LOV Domains in the design of photoresponsive enzymes. ACS Chem. Biol. 2018, 13, 1914-1920. [CrossRef] [PubMed]

84. Kumar, M.; Grzelakowski, M.; Zilles, J.; Clark, M.; Meier, W. Highly permeable polymeric membranes based on the incorporation of the functional water channel protein aquaporin Z. Proc. Natl. Acad. Sci. USA 2007, 104, 20719-20724. [CrossRef]

85. Chowdhury, R.; Ren, T.; Shankla, M.; Decker, K.; Grisewood, M.; Prabhakar, J.; Baker, C.; Golbeck, J.H.; Aksimentiev, A.; Kumar, M.; et al. PoreDesigner for tuning solute selectivity in a robust and highly permeable outer membrane pore. Nat. Commun. 2018, 9, 1-10. [CrossRef]

86. Licausi, F.; Giuntoli, B. Synthetic biology of hypoxia. New Phytol. 2020. [CrossRef] [PubMed]

87. Diederichs, T.; Pugh, G.; Dorey, A.; Xing, Y.; Burns, J.R.; Hung Nguyen, Q.; Tornow, M.; Tampé, R.; Howorka, S. Synthetic protein-conductive membrane nanopores built with DNA. Nat. Commun. 2019, 10,1-11. [CrossRef]

88. Ryu, H.; Fuwad, A.; Yoon, S.; Jang, H.; Lee, J.C.; Kim, S.M.; Jeon, T.J. Biomimetic membranes with transmembrane proteins: State-of-the-art in transmembrane protein applications. Int. J. Mol. Sci. 2019, 20, 1437. [CrossRef]

89. Alvarez, P.J.J.; Chan, C.K.; Elimelech, M.; Halas, N.J.; Villagrán, D. Emerging opportunities for nanotechnology to enhance water security. Nat. Nanotechnol. 2018, 13, 634. [CrossRef]

90. Kim, J.; Campbell, A.S.; de Ávila, B.E.F.; Wang, J. Wearable biosensors for healthcare monitoring. Nat. Biotechnol. 2019, 37, 389-406. [CrossRef]

91. Bartke, S.; Hagemann, N.; Harries, N.; Hauck, J.; Bardos, P. Market potential of nanoremediation in Europe-Market drivers and interventions identified in a deliberative scenario approach. Sci. Total Environ. 2018, 619, 1040-1048. [CrossRef] [PubMed]

92. Medina-Pérez, G.; Fernández-Luqueño, F.; Vazquez-Nuñez, E.; López-Valdez, F.; Prieto-Mendez, J.; Madariaga-Navarrete, A.; Miranda-Arámbula, M. Remediating polluted soils using nanotechnologies: Environmental benefits and risks. Pol. J. Environ. Stud. 2019, 28,1-18. [CrossRef]

93. Kumar, S.R.; Gopinath, P. Nano-bioremediation: Applications of nanotechnology for bioremediation. In Handbook of Advanced Industrial and Hazardous Wastes Management, 1st ed.; Wang, K.L., Wang, S.M.-H., Hung, Y.-T., Shammas, N.K., Chen, J.P., Eds.; CRC Press: Boca Raton, FL, USA, 2009; Volume 1, pp. $27-48$.

94. Sun, Y.; Liang, J.; Tang, L.; Li, H.; Zhu, Y.; Jiang, D.; Song, B.; Chen, M.; Zeng, G. Nano-pesticides: A great challenge for biodiversity? Nano Today 2019, 28, 100757. [CrossRef]

95. Lead, J.R.; Batley, G.E.; Alvarez, P.J.J.; Croteau, M.N.; Handy, R.D.; McLaughlin, M.J.; Judy, J.D.; Schirmer, K. Nanomaterials in the environment: Behavior, fate, bioavailability, and effects-An updated review. Environ. Toxicol. Chem. 2018, 37, 2029-2063. [CrossRef]

96. Vázquez Núñez, E.; de la Rosa-Álvarez, G. Environmental behavior of engineered nanomaterials in terrestrial ecosystems: Uptake, transformation and trophic transfer. Curr. Opin. Environ. Sci. Health 2018, 6, 42-46. [CrossRef]

97. Rasmussen, K.; González, M.; Kearns, P.; Sintes, J.R.; Rossi, F.; Sayre, P. Review of achievements of the OECD Working Party on Manufactured Nanomaterials' Testing and Assessment Programme. From exploratory testing to test guidelines. Regul. Toxicol. Pharmacol. 2016, 74, 147-160. [CrossRef]

98. Kica, E.; Wessel, R.A. Transactional arrangements in the governance of emerging technologies: The case of nanotechnology. In Embedding New Technologies into Society: A Regulatory, Ethical and Societal Perspective, 1st ed.; Bowman, D.M., Stokes, E., Rip, A., Eds.; CRC Press: Boca Raton, FL, USA, 2017; pp. $219-257$.

99. Hess, D.J.; Lamprou, A. Nanotechnology and the environment. In Nanotechnology and Global Sustainability, 1st ed.; Maclurcan, D., Radywyl, N., Eds.; CRC Press: Boca Raton, FL, USA, 2011; pp. 50-73.

100. Singh, D.; Wohlleben, W.; De La Torre Roche, R.; White, J.C.; Demokritou, P. Thermal decomposition/incineration of nano-enabled coatings and effects of nanofiller/matrix properties and operational conditions on byproduct release dynamics: Potential environmental health implications. NanoImpact 2019, 13, 44-55. [CrossRef] 
101. Song, Y.; Hou, D.; Zhang, J.; O'Connor, D.; Li, G.; Gu, Q.; Li, S.; Liu, P. Environmental and socio-economic sustainability appraisal of contaminated land remediation strategies: A case study at a mega-site in China. Sci. Total Environ. 2018, 610, 391-401. [CrossRef]

102. Rafique, M.; Tahir, M.B.; Sadaf, I. Nanotechnology: An Innovative Way for Wastewater Treatment and Purification. In Advanced Research in Nanosciences for Water Technology; Springer: Cham, Switzerland, 2019.

(C) 2020 by the authors. Licensee MDPI, Basel, Switzerland. This article is an open access article distributed under the terms and conditions of the Creative Commons Attribution (CC BY) license (http://creativecommons.org/licenses/by/4.0/). 